\title{
A Magyar Királyi Honvédség páncélozott eszközökkel felszerelt felderítő csapatai
}

A 2. gépkocsizó dandár 1941. április 11-éről 12-ére éjjel érkezett meg Mélykút - Jánoshalma - Kisszállás területére. ${ }^{158}$ Azonban nem sikerült elérnie a teljes feltöltést erre az időpontra, emiatt a dandár egészségügyioszlop, lőszerkezelő-oszlop, és a felderítő-zászlóalj puskásszázada és árkászszakaszának hátrahagyásával vonult el.

A dandár 12-én 13 órakor parancsot kapott, hogy erői zömével érje el Zombor és Kerény térségét, míg részeivel Bácsgyulafalvát. Tartsa az összeköttetést az I. hadtest csapataival, hajtson végre felderítést Újszivác, Kula, Újverbász irányában, tartson összeköttetést Topolya és Kossuthfalván át az előrenyomuló 2. lovasdandárral.

A dandárparancsnok intézkedésére felállították a Sándor-csoportot (Pk. Sándor István alezredes, a 4. gépkocsizászlóalj parancsnoka) és állományába szervezték a 4. gépkocsizó zászlóaljon kívül, a 2. felderítő-zászlóaljat (az 1. könnyű harckocsiszázad kivételével), a 12. kerékpáros üteget, a 2. légvédelmi gépágyús üteg két fél-szakaszát és a 2. gépkocsizó utászszázad felét. A Sándor-csoport 15 óra 30 perckor indult meg Bácsbokodon át Zomborra.

Közben a gyorshadtest parancsnoka a megváltozott harcászati helyzet miatt (az V. hadtest és a 2. lovasdandár részei Szabadkát már elérték, és a Duna mentén vezető utak csaknem járhatatlanok voltak) új feladatot szabott a 2. gépkocsizó dandár részére. E szerint a Sándor-csoport azonnali indulással törjön előre Kisszállás, Tompa, Szabadka, Topolyán át Újverbász, Szenttamás területére, itt létesítsen hídfőt és derítsen fel Újvidék irányában.

A dandár többi részéből létrehozva a Benda-csoportot (Pk. Benda alezredes, a dandár parancsnokhelyettese), állományában az 5 . és a 6 . gépkocsizó zászlóalj, a felderítő-zászlóalj egy könnyű harckocsiszázada, a 2. gépkocsizó könnyű tüzérosztály, a 11. kerékpáros üteg, az utászszázad fennmaradó része, három légvédelmi gépágyús félszakasz és a híradó század.

Feladata, hogy a Sándor-csoport után indulva Kisszállás, Tompa, Szabadka, Topolyán át meneteljen Kishegyes, Emőd, Bajna Topolya területére és ott biztosítva szállásoljon el.

18 órakor a dandár vezérkari főnöke érte utol egy új paranccsal, hogy annak megfelelően az új menetvonalon, Szabadkán át - Verbász és Szenttamás irányában - törjön előre, majd létesítsen ott hídfőt.

A dandár 2. és 3. menetlépcsőjét közben a dandár vezérkari főnöke javaslatára (hivatkozva a rossz, nehezen járható utakra) megfordították és a dandár zömével együtt Szegeden át meneteltek Szabadkára, hogy onnan folytassák az elörevonásukat a menetcéljuk felé.

A Sándor-csoport első lépcsője folytatta feladatát a már a megkezdett menetvonalon. A kötelék este 9 órakor érkezett Szabadkára, ahol utasították, hogy Topolyánál várja a további parancsokat. Azonban az előrevonás során a felderítő járőre Kishegyesnél ellenséges erőkön ütött rajta, elővédje pedig Topolyától délre szintén harcba lépett.

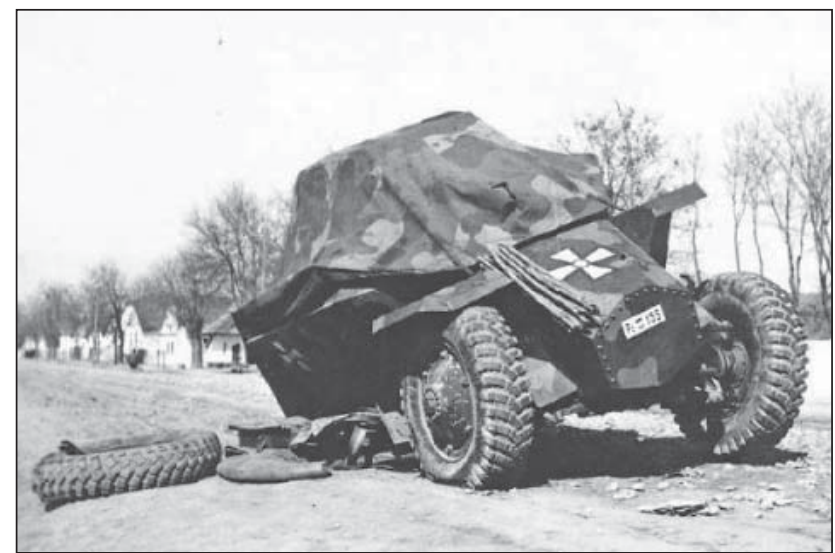

94. ábra. Egy aknára futott 39M Csaba páncélautó a magyar csapatok bevonulása idején (Fortepan 76992)

A Sándor-csoport este 22.12 órakor jelentett a dandár parancsnokának az akkor elért helyzetéről és az elhatározásáról, hogy 13-án hajnalban folytatja előretörését.

A csoport Nagyfény község északi területét 13-án hajnali 2 óráig megtisztította a szórványos lövöldöző csetnikektől ${ }^{159}$ és teljesen begyülekeztették a csoport 1. lépcsőjét, illetve részben a 2. lépcső zömét. Mivel a köteléknek 03.30ig nem volt rádióösszeköttetése, a dandárral beérkező 2. lépcső parancsnokától itt kapta meg a dandár vezérkari főnökétől kapott parancsot, hogy a Topolya délen be kell várniuk a zöm felzárkózását. Az elővéd jelentette, hogy saját lovas kötelékek már kiérkeztek Bácskossuthfalva és Csantavér területére, s hajnalban tervezik a továbbnyomulást.

A csatorna hídjainak robbantásra való előkészületeiről szóló lakossági információk miatt, illetve feltételezve, hogy a dandár zöme várhatóan 13-án, a délutáni órákban beérkezik, Sándor alezredes elhatározta, hogy Szenttamásra előretör és birtokba veszi a Ferenc-csatorna átkelőhelyeit. Mivel a dandárparancsnoksággal nem tudott összeköttetést teremteni, így nem tudta elhatározását jelenteni az elöljárójának. Ennek megfelelően a csoport felderítő-járőre és az elővédje 4 órakor kezdte meg az előretörését Szenttamás felé, mivel nem volt tudomásuk arról, hogy a 2. lovasdandár csoportja már útban van a város felé. 160

Útban Szenttamás felé, Topolyát mintegy 4 km-re elhagyva, a 4. gépkocsizó zászlóalj és az elővéd előtt tevékenykedett a felderítő járőr. A dr. Puky Ferenc zászlós páncélgépkocsi-szakaszával a felderítés során visszavonuló ellenséges csapatot fedezett fel. ${ }^{161}$ A páncélgépkocsiszakasz lerohanta őket, semlegesítette páncéltörő ágyúit, majd az útról letérő oszlop mélységén többször végigfutva, a menekülő ellenséget szétszórta. Puky zászlós páncélgépkocsija több találatot is kapott - többek között ellőtték 
délvidéki bevonulás első hősi halottja volt - társai a páncélgépkocsijukon szállították Szentlászló községbe. Az ezrednyi hadifogolyra a felderítő-zászlóalj önként jelentkező katonái vigyáztak, amíg az erre kijelölt alegység át nem vette, hogy hátrakísérje őket. ${ }^{167}$

A jugoszláv egység fogságba ejtése után az 1 . felderítőzászlóalj folytatta előrevonását és 16 órakor, mint az első magyar egység, beérkezett Újvidékre. A dandár zöme (1. és 3. gépkocsizó zászlóalj, 1. gépvontatású könnyű tüzérosztály, 1. gépkocsizó légvédelmi gépágyús üteg, dandárvonat) Zombor- Kerény - Kula - Bácskereszttúr - Liliomos - Pinczéd - Ósóvé - Petrőcz - Dunagálos - Újfutak menetvonalon este fél 8-kor érkezett be a városba. Az ünnepélyes fogadtatás után a seregtest Újvidéken elszállásolt.

A 2. gépkocsizó zászlóalj a IV. kerékpáros zászlóaljjal együtt gyorsbürün átkelt a Ferenc-csatornán és este 7 órakor érte el Dernyét, ahol az éjszakát töltötte.

A dandár 10. kerékpáros zászlóalja hajnali 5 órakor indult Garáról, majd Zomborban, egy háromórás pihenő megtartása után, tovább folytatta menetét Kerény - Kula Újverbász útvonalon Újvidékre, de oda csak másnap délután 2-kor érkezett meg, mivel Újverbásznál ellenséges erőkbe ütközött. ${ }^{168}$

A gyorshadtest-parancsnoksága a 2. gépkocsizó dandárról szóló első információkat - a már a módosított utasításának kiadása után - 10 óra 50 perckor kapta meg, mielőtt áttelepült volna Újverbászra. A jelentés szerint reggel 4 órakor a dandár zöme Szabadkától keletre, csak a Körös patakig jutott. ${ }^{169}$ Újabb összekötő tisztek kiküldése után, a 14.40-kor, a 2. gépkocsizó dandár elővédje szerepét betöltő Sándor-csoporttól kapott jelentés tisztázta az „eltűnt” két dandár helyzetét. Kiderült, hogy mindkét dandár - a 2. lovasdandár Topolyáról, a 2. gépkocsizó dandár, illetve annak elővédje - egy és ugyanazon cél, a szenttamási híd felé törekszik, hogy azon keresztül érjen be Újvidékre. ${ }^{170}$

A kirendelt összekötő tisztek közül az egyik menet közben érte utol a hadtestet, s pontosította a 2. lovas- és 2 . gépkocsizó dandár helyzetét: mindkét seregtest Topolyáról, illetve Szabadkáról Topolyán át, a szenttamási hídon át Újvidék felé tart. Mialatt a szenttamási hídnál a két dandár előretolt erői harcban álltak, a dandárok többi alakulata folytatta előrenyomulását a részükre meghatározott irányba. ${ }^{171}$

A szenttamási híd birtoklásáért folytatott harc a délvidéki hadműveletek egyetlen olyan harci eseménye volt, ahol a magyar csapatok az ellenség szervezett védelme ellen vették fel a harcot.

A szenttamási hidat két támadó csoportosítás külön-külön kívánta megszerezni. Ez abból a furcsa helyzetből adódott, hogy a két seregtesttel - amelyekből e csoportosítások alakultak - nem volt összeköttetés a hadműveletek második napján.

Az egyik támadó csoportosítás a 2. lovasdandár állományából 12-én 23 órakor megalakult Kozocsa-csoport (Kozocsa József ezredes, páncélos zászlóaljparancsnok vezetése alatt). Állományába a 2. páncélos zászlóalj megerősítésére megkapott egy fél lovas gépkocsizó utászszázadot, a 4. gépvontatású könnyű tüzérosztály egy ütegét, és a 15. kerékpáros zászlóaljtól egy fél kerékpáros századot. Feladatul kapta, hogy Topolyára felzárkóztatva a lemaradt alosztályait, még az éjszaka folyamán törjön elöre Szenttamásra, azonnal keljen át a Ferenc-csatornán, és a túlparton képezzen szűkebb hídfőt.

A másik támadó csoportosítás 12-én 16 órakor a 2. gépkocsizó dandár által létrehozott Sándor-csoport (parancsnoka a 4. gépkocsizó zászlóalj parancsnoka, Sándor István alezredes) volt. A zászlóaljat megerősítették a 2. felderítő-

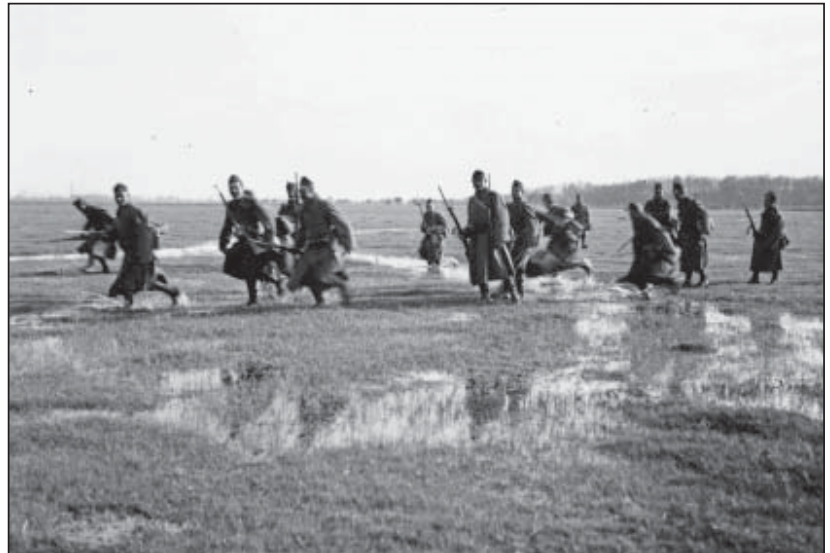

97. ábra. Jelentős akadályozó tényező volt az inkább csak gyalogosan járható terep (Fortepan 107533)

zászlóaljjal (a könnyű harckocsiszázad nélkül), a 12. kerékpáros üteggel, két légvédelmi gépágyús fél-szakasszal és egy utászszakasszal. Feladatul kapta, hogy törjön előre Kisszállás - Tompa - Szabadka - Topolyán át Új-Verbász - Szenttamás területére, itt létesítsen hídfőt és derítsen fel Újvidék irányában. A Sándor-csoportnak - mivel a 2. gépkocsizó dandár Szabadka előtt visszafordult és Szegeden keresztül próbálta elérni menetcélját -, csak a 4. zászlóalj (egy puskás század nélkül), a 2. felderítő-zászlóalj egy könnyű harckocsi- és páncélgépkocsi-századával, valamint egy légvédelmi gépágyús fél-szakasz állt rendelkezésére. Szabadka dél területén csatlakozott a csoporthoz a korábban említett ejtőernyős század.

A Kozocsa-csoport csak 13-án 0 órától kezdte meg a gyülekezést Topolyán. Sándor ezredes csoportja ekkor érkezett Nagyfény észak területére, ahol felzárkóztatta csoportját. A csoport felderítő járőre és az elővédje (állományában a 4. gépkocsizó zászlóalj 1 . százada, egy géppuskás szakasz, egy páncélgépkocsi-szakasz, egy árkászszakasz és egy páncéltörő ágyús szakasz) ekkor már Topolyán volt. Velük vette fel Kozocsa ezredes az összeköttetést.

Topolyáról 03.30-kor indult meg a Kozocsa-csoport az addig beérkezett páncélgépkocsi-századdal, a 4. gépvon-

98. ábra. Az 1. felderítő zászlóalj 39M Csaba páncélgépkocsija a Délvidéken

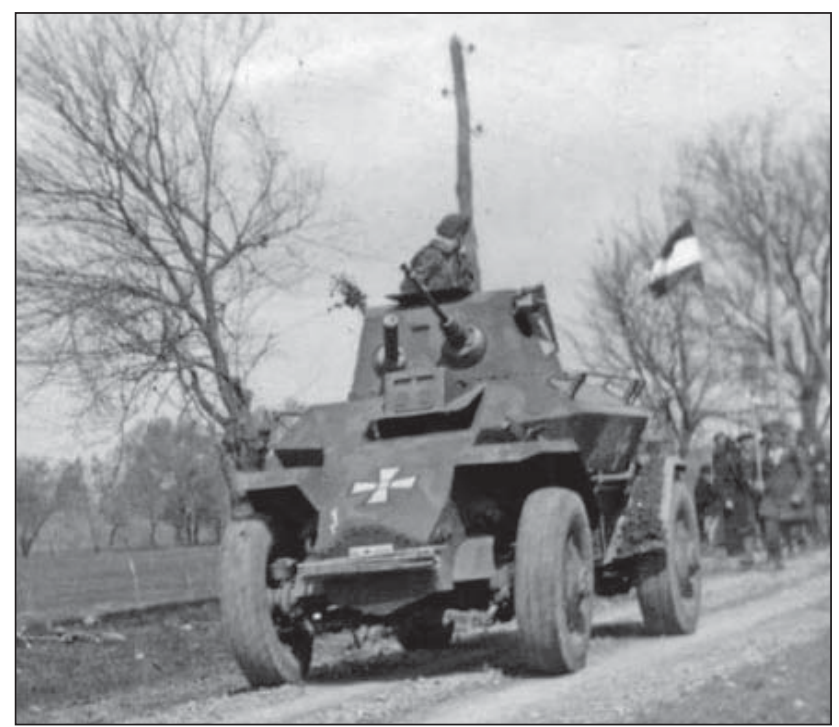




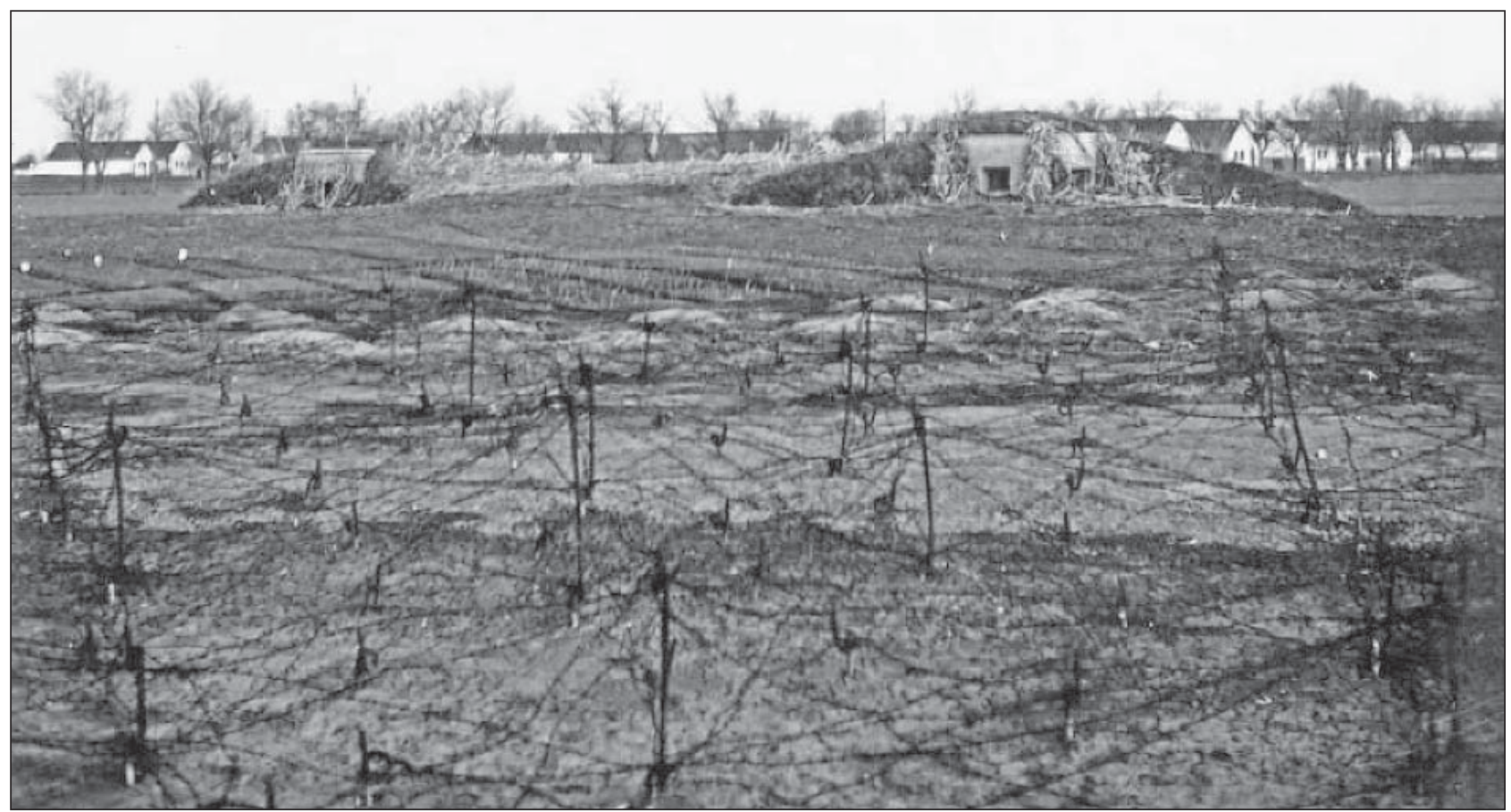

99. ábra. Bunkerek és drótakadályok egy délvidéki falu közelében (Fortepan 76984)

tatású osztály egy ütegével, egy légvédelmi gépágyús szakasszal és egy gépkocsizó utászszakasszal. A be nem érkezett kerékpáros alegység helyett a Sándor-csoport elővédjének egy puskás szakaszát vitte magával. Már indulásukkor jelentették a páncélgépkocsival ellátott felderítők, hogy az ellenség ellenállása nélkül elérték Kishegyest és 6 órára zavartalanul elérték Szenttamás északi szegélyét, ahol a község felé tartó 10-15 főnyi visszavonuló csoportot figyeltek meg.

A Kozocsa-csoport 6 óra után hatolt be a községbe, ahol minden oldalról, de különösen a templomtoronyból erős gyalogsági fegyvertüzet kaptak. Egy lövészszakasz és a gépágyús szakasz tűz alá vette a templomtornyot és a padlásokat, egyben járőröket indítottak a környező házak megtisztítására, amit 9 óráig sikeresen befejeztek.

A Sándor-csoport felzárkóztatta állományát (4. gépkocsizászlóalj zöme, a légvédelmi gépágyús szakasz és az ejtőernyős-század) Nagyfény térségében és 4 órakor megindult. A felderítő járőre és elővédje együtt menetelt a Kozocsa-csoporttal, de Szenttamásnál megállva az elővéd jelentette, hogy az ellenség a községben védelemre rendezkedett be és erős tűzerejü ellenséggel lépett harcba. Erdélyi József százados, a 2. felderítő-zászlóalj páncélgépkocsi-századának parancsnoka, még az elővédet is megelőzve, páncélgépkocsin személyesen derítette fel a Szenttamásin kialakult helyzetet. Kiderült, hogy a szenttamási védelem kiépített, erődített vonalakra támaszkodik. A helyszínre érkező csoport parancsnoka látta, hogy a Szenttamás körül kiépített erődvonalban csetnikek és az ellenséges gyalogság harcol. A saját felderítő járőre és az elővédje mintegy 400 méteres szélességben lassan támadott, amit a saját páncélgépkocsik az útról letérve - de elakadva - a tüzükkel támogattak. Mivel Kozocsa ezredes csapatai már a községben harcoltak, Sándor alezredes önállóan megkezdte a külső harc vezetését.

A beérkezett 2. gépkocsizó puskás századot a géppuskás századdal, a rohamszakaszával és páncéltörő ágyús rajával az elővéd jobb szárnya mellett harcba vetette azzal a céllal, hogy a községbe betörve érjék el a hidat és vegyék azt birtokba. A csoportosítás jobb szárnyára irányította az ejtőernyős századot, hogy a község nyugati kijáratát mielőbb elérve kelljen át a csatornán, és a déli irányból kísérelje meg birtokba venni a hidat. A saját hátának biztosítását pedig az akkor beérkezett 15. kerékpáros zászlóalj egy századának szabta feladatul.

Kemény helységharc fejlődött ki, ahol a védők igyekeztek kihasználni a küzdő magyar egységek közti réseket. A beérkező 2 . lovasdandár kisharckocsi-százada, amely reggel még a Szabadka déli részén harcolt, Sándor alezredes alárendeltségbe került, aki azt a településtől északra tartalékba helyezte.

9 órakor a Kozocsa-csoportba tartozó 4./1. gépvontatású könnyü üteg parancsnoka, Szabó Gyula százados elhatározta, hogy a híd birtokbavételével megakadályozza annak felrobbantását. Egy tűzszakaszt előrevont a hídhoz, amely réslövéssel kilőtte a túlparti robbantó helyéül szolgáló betonmegfigyelőt. A hozzá beosztott gépkocsizó utászrajjal áthajtott a hídon, elvágva a gyújtózsinórokat. Szabó százados a felderítő járőrrel, a lövegkezelőkkel és még 20-30 felfegyverzett polgári személlyel megszállta a szűkebb hídfőt. 10 óra 30 perckor jelentette a helyzetét Kozocsa ezredesnek. A jelentést Sándor alezredes is vette. Ezzel egyidejüleg az utászok megkezdték a hídra szerelt robbanóanyagok leszerelését, amelynek mennyisége 14 mázsa volt. A kapott jelentés alapján Sándor alezredes kirendelte a 4./2. puskás századát Szabó százados csoportjának leváltására, és a század biztosította a továbbiakban ezt a fontos hídfőt.

A szenttamási hidat hatórás harc árán, jelentős szerencsével sikerült épségben elfoglalni.

A 2. lovasdandár zöme a hídfő csata idején hajtotta végre az előrevonását.

A 15. kerékpáros zászlóalj 11 órakor érkezett Óverbászra, és Kulára egy biztosító részleget küldött ki. A zászlóalj árkászszakasza 2 és fél órán belül szükséghidat vert, majd átkeltek a csatornán és egy szükséghíd felépítése után éjjelre átvonult Új-Verbászra és ott biztosították a hídfőt. A szükséghíd olyan jól sikerült, hogy másfél napon keresztül az egész forgalom azon bonyolódott. ${ }^{172}$ 


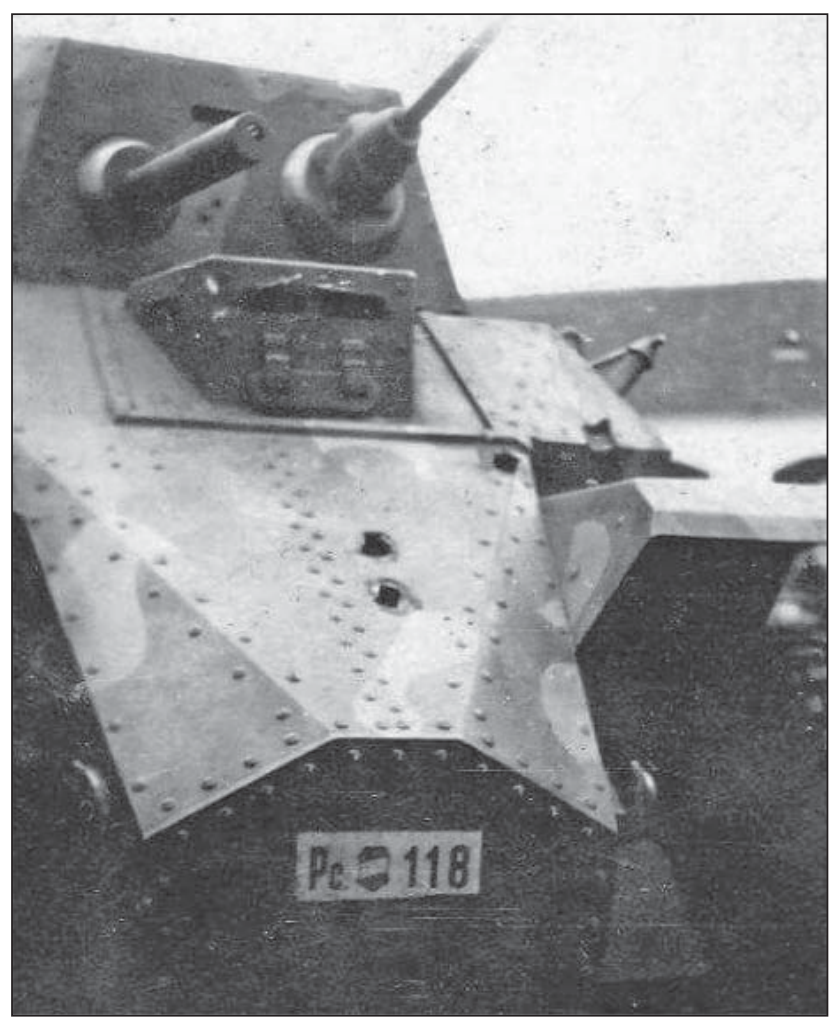

100. ábra. Kilőtt Csaba páncélautó

A 16. kerékpáros zászlóalj 9 órakor indult Topolyáról, és a csetnikek ellenállását többször is letörve, 11.30 órakor érkezett be Szenttamásra. Beérkezése után egy páncélgépkocsi-szakaszt és a nála lévő fél kerékpáros századot irányította a tőle mintegy 20 km-re keletre lévő Óbecse területére, amit a 2. huszárezred beérkezéséig biztosítottak.

A kerékpáros zászlóaljakkal együtt menetelő 4. gépvontatású tüzérosztály parancsnoksága és 2. ütege is 11.45kor beérkezett a községbe, amelyet a Sándor-csoport alárendeltségébe helyeztek.

Szenttamáson 16:30-kor újból lövöldözni kezdtek az elrejtőzött csetnikek, de a kerékpáros zászlóalj a 4. utászszázaddal együtt kíméletlenül elfojtotta azt.

$A z$ 1. huszárezred menete 12.30-kor indult Topolyán át Bács-feketehegyre, ahová 17 órára beérkezett és ott elszállásolt.

A 2. huszárezred és a 2. lovas tüzérosztály 10 órakor indult Csantavérről két oszlopban Óbecsére. A Topolyán át menetelő oszlop 18 órakor, a másik oszlop csak éjfél után ért be, ahol elszállásolt. Egy megerősített századdal biztosította a bácsföldvári hidakat. Megjegyzendő, hogy az ezred 12-én és 13-án összesen $130 \mathrm{~km}$-es utat tett meg. ${ }^{173}$

Sándor alezredes csoportja a déli órákig folytatta a község megtisztítását, kiegészítette a hídfő megszállását egy puskás szakasszal és rendezte állományát. 14 órakor a 2. lovasdandár-parancsnokság is megérkezett. A vele érkezett 4. gépvontatású tüzérosztály 2. ütegét az Újvidék felé továbbnyomuló Sándor-csoportnak rendelték alá, amely 15 órakor megkezdte a feladatát. Állománya a 4. gépkocsizó zászlóalj zöméből, a 2. felderítő-zászlóalj páncélgépkocsi- és 1. könnyű harckocsiszázadaiból, a lovasdandártól kapott 4. gépvontatású könnyű tüzérosztály 2. ütegéből, és egy fél légvédelmi gépágyús szakaszból állt.

A 2. lovas páncélos zászlóalj páncélgépkocsi-századának parancsnoka (Béldy főhadnagy) feladatul kapta, hogy a felderítő járőrrel törjön előre a bácsföldvári hídfő biztosí-

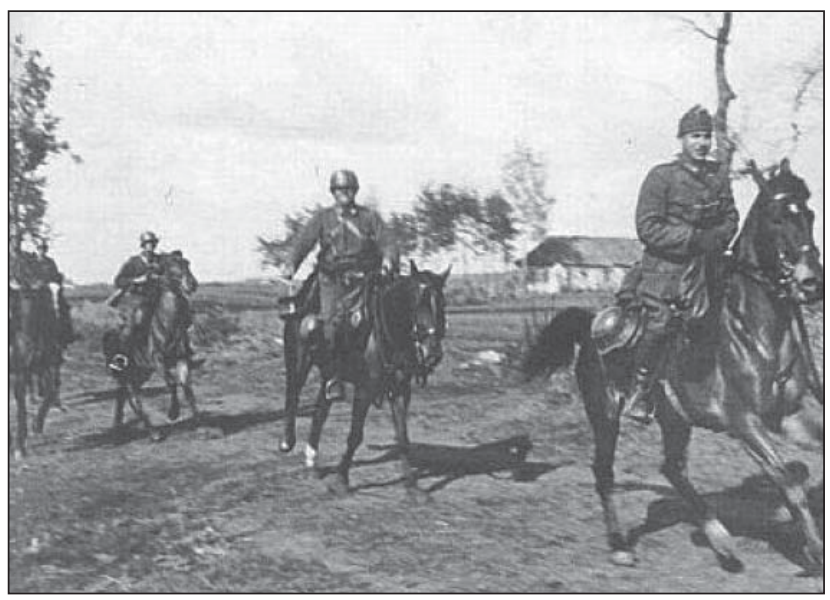

101. ábra. Magyar lovas felderítő járőr a Délvidéken

tására. Szőreg községben azonban ellenséges védelembe futottak. A kialakult harcban az ellenség két páncélgépkocsit kilőtt, Béldy főhadnagy és legénységéből 5 fő elesett, 2 fő pedig súlyosan megsebesült. ${ }^{174}$ Csak a gépkocsizó zászlóalj elővédjének tüzérségi támogatással biztosított gyors elöretörése után tudták kihozni a két páncélgépkocsit a hat hősi halottal. ${ }^{175}$ A 19.30-ig tartó harcokban a magyar csapatok is komoly veszteségeket szenvedtek, de végül, a település birtokba vétele után 200 ellenséges fegyverest ejtettek hadifogságba.

\section{JEGYZETEK}

158 HIM HL TGY 2191 Pokorny H. Délvidék 1941, 112 ;

159 Csetnikek: szerb irreguláris katonai alakulat tagjait jelöli. A német megszállás után a polgári emigráns kormányt támogató, angolbarát, de 1942-től a megszállókkal is megegyezést kereső, a kommunisták ellen is harcoló Draža Mihailović egységeinek a neve. - https://hu.wikipedia.org/wiki/Csetnik. A letöltés ideje: 2016. 12.10.

160 HIM HL TGY 2191 Pokorny H. Délvidék 1941, 114.;

161 Kiss Gábor Ferenc: Magyar Királyi Honvédség gyorscsapatai 1938-1941, Doktori (PhD) értekezés, Szegedi Tudományegyetem, Bölcsészettudományi Kar, Történelemtudományi Doktori Iskola, Szeged, 2012, 176.;

162 Klemenits Péter: Magyar páncélosok a délvidéki hadműveletben (1941. április);

163 HIM HL TGY 2191 Pokorny H. Délvidék 1941, 115.; 164 HIM HL TGY 2191 Pokorny H. Délvidék 1941, 115.;

165 HIM HL TGY 2191 Pokorny H. Délvidék 1941, 131.;

166 Kiss Gábor Ferenc: Magyar Királyi Honvédség gyorscsapatai 1938-1941, Doktori (PhD) értekezés, Szegedi Tudományegyetem, Bölcsészettudományi Kar, Történelemtudományi Doktori Iskola, Szeged, 2012, 180-181.

167 A volt m. kir. 1. honvéd felderítő zászlóalj története, Budapest, 2006, Dr. vitéz Tóth József magánkiadása, 111.;

168 HIM HL TGY 2191 Pokorny H. Délvidék 1941, 131.;

169 HIM HL TGY 2191 Pokorny H. Délvidék 1941, 131.;

170 HIM HL TGY 2191 Pokorny H. Délvidék 1941, 132.;

171 HIM HL TGY 2191 Pokorny H. Délvidék 1941, 131.;

172 Kiss Gábor Ferenc: Magyar Királyi Honvédség gyorscsapatai 1938-1941, Doktori (PhD) értekezés, Szegedi Tudományegyetem, Bölcsészettudományi Kar, Történelemtudományi Doktori Iskola, Szeged, 2012, 185.;

173 HIM HL TGY 2191 Pokorny H. Délvidék 1941, 133.;

174 HIM HL TGY 2191 Pokorny H. Délvidék 1941, XII. melléklet;

175 Kiss Gábor Ferenc: Magyar Királyi Honvédség gyorscsapatai 1938-1941, Doktori (PhD) értekezés, Szegedi Tudományegyetem, Bölcsészettudományi Kar, Történelemtudományi Doktori Iskola, Szeged, 2012, 186 